\title{
WAYANG KULIT JAWA TIMURAN CENGKOK TROWULAN: ASAL USUL DAN PETA PENYEBARANNYA
}

\author{
Bambang Suyono, Jojo Winarko, Darni \\ Universitas Negeri Surabaya
}

\begin{abstract}
Abstrak
Seni wayang kulit Jawa Timuran, ibarat mutiara yang bertebaran namun belum mendapat perhatian dengan baik. Identitasnya masih belum jelas. Belum ada usaha untuk mendokumentasikan, memperkenalkan, apalagi membinanya ke arah perkembangan yang lebih baik. Ironisnya, wayang kulit Jawa Timuran merupakan identitas masyarakat Jawa Timur.

Berkaitan dengan dicanangkannya pembelajaran kontekstual di sekolah dan perguruan tinggi, aset budaya daerah memegang peranan penting dalam pengembangan kurikulum dan penggalian materi yang berbasis konteks sosio budaya. Wayang kulit memiliki potensi untuk memperkaya substansi kurikulum dan materi ajar di sekolah dan perguruan tinggi. Sementara itu, selama ini, materi pembelajaran tentang wayang di sekolah masih berorientasi ke wayang kulit gaya Jawa Tengah. Bahasa baku Jawa Tengah merupakan kendala yang sangat berarti dalam apresiasi sastra wayang di sekolah. Kesulitan tersebut mengakibatkan belum adanya minat pengenalan dan pengahargaan siswa di sekolah akan nilainilai luhur budaya sendiri. Di perguruan tinggi, khususnya di jurusan Sendratasik dan Pendidikan Bahasa Daerah Unesa, materi kuliah juga masih berorientasi pada pertunjukkan wayang gaya Jawa Tengah. Kekhasan materi yang disampaikan dosen di perguruan tinggi akan dianut dan diamalkan mahasiswa di lapangan ketika sudah menjadi guru.
\end{abstract}

Kata kunci: wayang kulit, Jawa Timuran, Trowulan

\begin{abstract}
Abstrak
The leather puppet art in East Jawa is the identity of East Java region. Ironically, it had no attention as good as the modern arts. The problem is when it implemented in school, there were a lot of differences between East Java and Central Java tradition. The differences on language was too hard to understand by the student, so the student paid no attention and appreciation on it.. This article will show how it implemented in school as a specific major in Sendratasik and Javanese Program in Surabaya University. This article will describe how this traditional art will be identified, clasificated, and found its history.

Keywords: puppet, East Java, Trowulan

\section{PENDAHULUAN}

Wayang kulit Jawa Timuran yang akrab disebut wayang cek dong menurut pengamatan pendahuluan memiliki versi atau cengkok yang beragam. Antara lain ada wayang "Jawa Timuran" cengkok Porong, cengkok Trowulan, cengkok Malang, cengkok Surabaya, cengkok Jombang, dan cengkok Lamongan. Masingmasing cengkok tersebut memiliki kekhasan. Kekayaan gaya atau cengkok atau
\end{abstract}


versi tersebut justru memberikan keunikan yang berpotensi sebagai aset wisata lokal yang berwibawa.

Berangkat dari kondisi tersebut, wayang kulit Jawa Timuran harus segera digali untuk diidentifikasi, diklasifikasi, dan ditelusuri sejarahnya. Identitas yang jelas akan menjadi landasan pembinaan dan tindak lanjut implementasinya dalam substansi materi ajar kurikulum perguruan tinggi.

\section{Wayang Kulit sebagai Salah Satu Bentuk Folklor}

Wayang merupakan kesenian tradisional Jawa yang sangat populer dan tua usianya. Wayang sangat populer sejak jaman para Wali berdakwah agama Islam. Pada saat itu wayang dijadikan sarana dakwah yang sangat relevan. Karena populernya, sampai ada anggapan bahwa wayang ciptaan para Wali. Na mun, apabila diamati lebih jauh, sebenarnya wayang telah ada sebelum para wali datang di tanah Jawa. Hal tersebut dapat dilihat dari cerita wayang yang babonnya berasal dari India. Sedangkan pengaruh India telah ada jauh sebelum Islam masuk ke tanah Jawa.

Di antara kesenian daerah di Jawa Timur, wayang kulit merupakan satu kesenian daerah yang paling menonjol. Wayang kulit dijadikan sarana hiburan maupun sarana ritual dalam berbagai acara maupun hajatan. Dapat menyajikan hiburan wayang kulit dalam acara biasa maupun ritual merupakan suatu gengsi yang amat tinggi dalam masyarakat Jawa. Memang, dibanding kesenian daerah yang lain, pagelaran wayang kulit memerlukan dana yang lebih banyak. Di samping itu, ajaran budi luhur yang terkandung di dalamnya sampai sekarang masih menjadi tauladan dalam kehidupan masyarakat Jawa.

Berbicara masalah wayang, tidak lepas dengan dalang. Seorang dalang wayang kulit, menurut Ras (1985:4), meskipun ia hanya orang desa yang tidak terpelajar, oleh para penontonnya dianggap ahli seni sastra. Dalam waktu semalam dan seorang diri ia menyajikan pergelaran drama. Di samping unsur cerita narasi, ia juga menggunakan puisi kuna atau suluk, tembang macapat, dan dialog-dialog yang bersifat stereotipe.

Wayang kulit merupakan salah satu bentuk dari teater rakyat. Oleh Danandjaja teater rakyat, termasuk wayang kulit, dimasukkan pada folklor sebagain lisan (1984:22) Sebagai salah satu bentuk folklor wayang kulit memiliki ciri-ciri folklor seperti yang diungkapkan oleh Danandjaya (1984:3-4), yakni: (1) penyebaran dan pewarisannya biasanya dilakukan secara lisan; (2) bersifat tradisional; (3) ada dalam bentuk versi-versi; (4) bersifat anonim; (5) biasanya memiliki bentuk berumus atau berpola; (6) mempunyai kegunaan dalam kehidupan bersama suatu kolektif; (7) bersifat pralogis; (8) menjadi milik bersama dari suatu kolektif tertentu; (9) bersifat polos dan lugu.

Lebih khusus lagi, sebagai salah satu bentuk folklor sebagian lisan, Suripan Sadi Hutomo mengklasifikasikan seni wayang kulit sebagai sastra lisan yang setengah lisan (1991:60). Sastra lisan adalah kesusasteraan yang mencakup ekspresi kesusasteraan warga suatu kebudayaan yang disebarkan dan dituruntemurunkan secara lisan (dari mulut ke mulut) (Hutomo, 1991:1). Penggolongan yang dilakukan oleh Hutomo lebih tepat untuk memasukkan seni wayang sebagai 
sastra lisan yang setengah lisan. Sastra lisan setengah lisan termasuk pada kelompok folklor sebagian lisan.

\section{Dalang sebagai Pendukung Aktif}

Suatu kebudayaan mempunyai kelompok pendukung. Menurut konsep Von Sedow (1948), di dalam kebudayaan suatu bangsa ada yang dinamakan active bearers of tradistion dan pasive bearers tradition, artinya pemikul kebudayaan yang aktif dan pemikul kebudayaan yang pasif. Pemikul kebudayaan yang aktif adalah orang-orang yang aktif menerima dan mengembangkan warisan budaya, sedangkan penikul kebudayaan yang pasif adalah orang-orang yang pasif menerima warisan budaya (Hutomo, 1987:11).

Dalang wayang kulit sebagai pendukung kebudayaan yang aktif sangat besar perannya dalam upaya pelestarian seni wayang kulit. Di tangan mereka seni tersebut akan tetap hidup. Di samping berperan sebagai pelestari, mereka juga berperan sebagai pengembang dan pembaharu, seperti yang dikemukakan oleh Adre Harjana, bahwa sastra lisan memiliki tradisi kritik yang berbeda dengan sastra tulis (1994:11). Dalam seni wayang, dalang berperan ganda, sebagai pencerita dan sebagai kritikus, karena berkat kreativitasnya seni wayang dapat berkembang mengikuti perkembangan jaman. Sebagai contoh kami sebut dalang Joko Edan. Ia telah bertindak sebagai kritikus, yakni mengembangkan seni wayang sedemikian rupa sehingga dapat menarik kawula muda. Peran pendukung aktif ini sangat besar dan tugas yang diembannya sangat berat. Di samping berperan aktif sebagai pelestari, ia juga harus bekerja keras untuk mengembangkannya agar tidak ditinggalkan oleh pendukungnya.

\section{Gaya dan Corak Wayang Kulit}

Wayang kulit memiliki beberapa versi atau gagrak atau gaya. Kalau diamati, versi atau gagrak tersebut sebagian besar dibedakan menurut pemakaian bahasa atau dialek setempat, kecuali versi Yogyakarta dan Surakarta. Keduanya tidak dibedakan oleh bahasa, namun oleh corak wayang. Versi wayang kulit Surakarta mengembangkan corak wayang yang cenderung dinamis, sedangkan versi Yogyakarta melestarikan corak wayang Mataraman, tanpa melakukan perubahan. Menurut Nugroho (2001:9) hal tersebut sudah merupakan kesepakatan dua raja besar di Jawa Tengah, yakni Sunan Paku Buwono III dan Sri Sultan HB I. Bahwa Sunan Paku Buwono mendukung Sri Sultan HB I yang ingin melestarikan corak wayang Mataraman yang lugu, gagah, tegas, dan mengandung nilai-nilai perjuangan. Sedangkan beliau akan mengembangkan corak baru yang lebih dinamis, menarik perhatian, dan mengandung penafisiran-penafsiran baru. Istilah corak di sini dibedakan dengan gaya, versi, atau gagrak. Corak berkaitan dengan bentuk sunggingan atau tatahan wayang. Secara terus-menerus corak wayang Surakarta memang terus mengalami perkembangan, baik ukuran maupun hiasannya.

Wayang kulit di Jawa Timur, seperti telah disebut sebelumnya, menggunakan dua versi, yaitu versi Jawa Tengah dan Jawa Timuran. Versi Jawa Tengah meliputi dua versi yang disebut-sebut di atas, yaitu versi Yogyakarta dan Surakarta. Kedua versi tersebut disebut versi Jawa Tengah, karena keduanya 
menggunakan bahasa dengan dialek yang sama, yaitu bahasa Jawa keraton di Jawa Tengah, yang disebut-sebut sebagai bahasa Jawa baku. Antara kedua versi yang hidup di Jawa Timur, yakni versi Jawa Tengah dan Jawa Timuran, memiliki beberapa perbedaan. Perbedaan yang menonjol terletak pada bahasa yang digunakan. Wayang kulit versi atau gaya Jawa Tengah menggunakan bahasa Jawa dialek Jawa Tengah atau bahasa Jawa baku, sedangkan wayang gaya Jawa Timur menggunakan dialek Jawa Timur atau dialek Surabaya. Karakter khusus lainnya akan diuraikan berikut ini.

\section{Ciri Umum Wayang Kulit Jawa Timuran}

Wayang kulit Jawa Timuran memiliki karakter khusus. Karakter tersebut berkaitan dengan iringan atau instrumen pengiring, bentuk wayang, susunan adegan, bahasa dan penampilan dalang.

Alat pengiring pementasan wayang Jawa Timuran terdiri dari seperangkat alat musik Jawa yang disebut gamelan. Alat musik tersebut terdiri dari: bonang babak, bonang penerus, gambang, slenthem, kempul, kenong, saron, siter, rebab, demung, gender, kendhang, dan gong. Kendhang Jawa Timuran berbeda dengan Jawa Tengah. Kendhang Jawa Timuran lebih panjang dan lebih besar, sehingga kalau dipukul berbunyi dong...dong...dong. Berdasarkan bunyi kendhang tersebut, wayang Jawa Timuran juga disebut wayang cek dong. Cek berasal dari bunyi kecrek, beberapa lempengan logam yang disentuh dengan kaki dan berbunyi crek...crek...crek, kemudian diikuti bunyi kendhang dong....dong....dong (Susilo, 2001:38).

Pementasan wayang Jawa Timuran tidak pernah ketinggalan dengan tari Remo. Tari Remo merupakan tari khas Jawa Timur. Tari tersebut selalu menghiasi pementasan gaya Jawa Timur, seperti kesenian Ludruk. Tari Remo disajikan pada awal acara sebelum wayang dimulai. Tari Remo ditarikan oleh penari Remo putri dan putra. Selain tari Remo, juga disajikan gendhing-gendhing lancaran dan ladrang.

Bentuk wayang Jawa Timuran kecil-kecil, mengembangkan bentuk wayang Surakarta yang memang berukuran lebih kecil dibanding wayang gaya Yogyakarta. Demikian pula dengan tokoh. Wayang kulit Jawa Timuran memiliki tokoh-tokoh khas seperti Besut, Klamatdarum, Pak Mujeni, dan Pak Mundu. Tokoh-tokoh tersebut tidak ditemui di wayang Jawa Tengah, baik Surakarta mapun Yogyakarta.

Bahasa wayang Jawa Timuran seperti telah disinggung, menggunakan dialek Surabaya-an dan sekitarnya atau Gerbangkertasusila, yakni Gresik, Jombang, Mojokerto, Sidoarjo, dan Lamongan. Kosa kata khas Jawa Timuran seperti koen, barek, arek, embong, logor, molih, ndhok, dan sebagainya. Sedangkan narasi atau vokal dalang pada umumnya berbentuk bahasa indah. Ciri menonjol vokal wayang Jawa Timuran terletak pada nada yang digunakan, yakni cenderung tinggi (Parwoto, 1985:46).

Dalang wayang Jawa Timuran pada waktu pentas berpenampilan khas Jawa Timuran. Pada umumnya mereka mengenakan blangkon Jawa Timuran, bawahan 
kain panjang atau sewek, atasan beskap, tidak mengenakan keris. Dalang wayang kulit Jawa Timuran memiliki penampilan yang khas Jawa Timuran.

Di samping perbedaan tersebut, di dalam tubuh wayang kulit Jawa Timuran terdapat versi atau cengkok yang lebih beragam. Seperti telah diuraikan, bahwa wayang kulit Jawa Timuran memiliki sedikitnya 6 cengkok, yaitu cengkok Porong, Malang, Surabaya, Lamongan, Jombang, dan Mojokerto. Keenamnya meskipun terikat dalam bentuk wayang Jawa Timuran yang memiliki ciri utama memakai bahasa dialek Jawa Timuran, di dalamnya masih memiliki keunikan-keunikan yang beragam. Dalam penelitian ini diteliti keenam cengkok tersebut. Penelitian akan dilakukan dalam dua tahap.

\section{Style dan Stilistika}

Style (gaya bahasa) merupakan cara pengucapan bahasa dalam prosa atau bagaimana seorang pengarang mengungkapkan sesuatu yang akan dikemukakan. Demikian pula pendapat Leech \& Short bahwa makna style lebih menyaran kepada pengertian cara penggunaan bahasa dalam konteks tertentu, oleh pengarang tertentu, untuk tujuan tertentu, dan sebagainya (Nurgiantoro, 2002:276).

Hakekat style sebenarnya merupakan teknik pemilihan ungkapan kebahasaan yang dirasa dapat mewakili sesuatu yang akan diungkapkan. Oleh karena itu style dapat bermacam-macam sifatnya bergantung konteks dimana dipergunakan, selera pengarang, dan tujuan penuturan sendiri.

Selanjutnya stilistika (stylistic) menyaran pada pengertian studi tentang style. Di dalam Kamus Besar Bahasa Indonesia (1997:963) stilistika adalah ilmu tentang penggunaan bahasa dan gaya bahasa di dalam karya sastra. Stilistika tidak dapat diterapkan dengan baik tanpa dasar linguistik yang kuat, karena salah satu perhatian utamanya adalah kontras sistem bahasa karya sastra dengan penggunaan bahasa pada umumnya. Sedangkan menurut Wellek (2001: 222-3), stilistika secara luas meneliti semua teknik yang dipakai untuk tujuan ekspresif tertentu dan meliputi wilayah yang lebih luas dari sastra atau retorika.

Sujiman (1993:14) mengatakan bahwa pengkajian stilistik meneliti gaya sebuah teks sastra secara rinci dengan secara sistematis memperhatikan preferensi penggunaan kata atau struktur bahasa, mengamati antara hubungan pilihan itu untuk mengidentifikasi ciri-ciri stilistik (stylistic features) yang membedakan pengarang, karya, tradisi, atau periode tertentu dari pengarang. Lebih lanjut juga dikatakan bahwa ciri-ciri stilistik tersebut dapat bersifat fonologi (pola bunyi, bahasa, matra, rima), sintaksis (tipe struktur kalimat), leksikal (diksi, frekuensi penggunaan kelas kata tertentu), atau retorika. (majas, citraan).

Sedangkan Aminuddin (1995:309) mengemukakan bahwa stilistik adalah kajian tentang cara penggunaan sistem tanda yang dilakukan sesuai dengan konstruk menyangkut jenis sistem tanda yang dijadikan sasaran kajian. Jika itu mangacu pada sistem dalam karya sastra, maka, kajian harus memperhatian karakteristik penggunaan sistem tanda dalam karya sastra selain difungsikan untuk menyampaikan pesan juga difungsikan untuk memberikan efek emotif tertentu. Abrams juga mengemukakan bahwa unsur style terdiri dari unsur fonologi, sintaksis, leksikal, retorika yang berupa karakteristik penggunaan bahasa figuratif, pencitraan, dan sebagainya (Nurgiantoro, 2002:289). 
Dari berbagai pendapat di atas, dapat dirumuskan bahwa style merupakan teknik pengungkapannya, sedangkan stylistic atau stilistika adalah studi tentang teknik pengungkapan yang digunakan pengarang. Bahasa merupakan sarana atau media pengungkapan utama yang digunakan dalam karya sastra. Hal tersebut selaras dengan pengertian yang diberikan oleh Toolan (1998:viii) bahwa stilistika adalah studi tentang bahasa dalam satra.

Teori stilistika ini akan digunakan untuk menggali stile atau gaya yang dimiliki masing-masing dalang. Stile tersebut memberikan warna keunikan atau cengkok dalam istilah pewayangan.

\section{Metode Penelitian}

Penelitian yang akan dilakukan ini menggunakan model penelitian kualitatif. Menurut Idrus (2007:14), penelitian kualitatif adalah prosedur penelitian yang menghasilkan data deskriptif berupa kata-kata tertulis dan lisan tentang orang-orang atau perilaku yang dapat diamati. Oleh karena itu, sifat pnelitian kualitatif adalah deskriptif, yaitu menggambarkan secara mendalam tentang situasi atau proses yang diteliti. Penggambaran secara mendalam tersebut oleh James Danandjaja (1990:99) disebut pula sebagai pemahaman mendalam atau verstahen. Model penelitian kualitatif dalam bidang folklore menurut Danandjaja (1990: 89) disebut juga etnografi. Dijelaskan lebih jauh oleh Spradly (1997:11), bahwa dengan etnografi peneliti berupaya mendiskripsikan kebudayaan baik secara implisit maupun eksplisit yang terungkap melalui perkataan, tingkah laku, dan berbagai artefak.

Penelitian ini, melalui desain penelitian kualitatif akan dideskripsikan tentang kekhasan pertunjukkan wayang kulit Jawa Timuran yang pada akhirnya akan diperoleh peta penyebaran wayang Jawa Timuran. Deskripsi untuk menemukan kekhasan atau cengkok dalang akan dipandu oleh teori stilistika. Hasil deskripsi tersebut akan dihubungkan dengan pendapat tokoh masyarakat dalam bidang wayang kulit Jawa Timuran sebagai upaya penelusuran untuk memperoleh jawaban tentang sebab musabab terjadinya berbagai cengkok dalam pertunjukkan wayang Jawa Timuran.

\section{Sumber Data}

Sumber data penelitian menurut Idrus (2007:36) adalah orang-orang yang dianggap tahu tentang fenomena yang diteliti dan dipilih berdasarkan kriteria yang disepakati peneliti sendiri, sehingga jumlahnya terbatas. Berdasaran pengamatan awal yang sudah dilakukan, sumber data dalam penelitian tahun pertama ini adalah dalang wayang kulit Jawa Timuran yang tersebar di 3 wilayah yaitu: Surabaya, Porong, dan Malang. Ketiga wilayah tersebut merupakan pusat berkembangnya wayang kulit Jawa Timuran yang memiliki gaya pementasan yang berbeda satu dengan yang lainnya.

Dijelaskan pula oleh Idrus (2007: 36) bahwa penelitian kualitatif tidak menuntut subyek yang banyak, namun orang yang betul-betul tahu tentang fenomena yang sedang diteliti. Sejalan dengan pendapat tersebut, maka sumber data dalam penelitian ini dalang senior di wilayah yang diteliti. Semua dalang 
senior di wilayah tersebut akan dijadikan sumber data dalam penelitian ini. Dalang senior merupakan dalang yang berperan sebagai cikal-bakal atau pengembang cengkok wayang kulit Jawa Timuran di wilayahnya.

Penentuan aspek kesenioran dalam menentuan sumber data tidak hanya semata-mata aspek kesenioran saja, juga berdasarkan pertimbangan bahwa dalang senior yang sebagian besar menjadi ketua Pepadi di kabupatennya, masih memiliki kharisma dan memang dihormati oleh dalang-dalang yunior. Nilai dan adat Jawa sangat dipegang teguh oleh para dalang.

Penentuan sumber data juga dilakukan dengan proses musyawarah dalam tubuh Pepadi setempat. Organisasi dalang tersebut sangat memegang peranan dalam perkembangan kesenian wayang didaerahnya. Keputusan Pepadi merupakan petunjuk dalam penentuan sumber data dari pihak dalang. Mungkin saja dalang paling senior tidak menjadi sumber data, karena alasan yang bisa dipertanggungjawabkan. Namun selanjutnya dalang senior tersebut dan pertunjukkannya akan dijadikan sumber data dalam penggalian kekhasan cengkok wayang.

Sumber data penelitian ini adalah Ki Pitoyo yang terkenal dengan sebutan Dalang Pit, mirip dengan nama tokoh cengkok Trowulan yakni Ki Pit Asmoro. Ki Pitoyo merupakan dalang senior di wilayah Trowulan. Beliau juga merupakan murid dari Ki Pit Asmoro meskipun beliau belajar secara autodidak melalui pertunjukkan dan kaset pertunjukkan Ki Pit Asmoro. Pertunjukkan wayang Ki Pitoyo diambil satu cerita sebagai sumber data. Cerita tersebut berjudul Pandhawa Meguru.

Sumber data penelitian juga diambil dari para tokoh masyarakat dalam bidang wayang kulit Jawa Timuran. Pengetahuan dan ide para tokoh tersebut akan memperjelas sebab musabab terjadinya berbagai cengkok dalam tubuh wayang Jawa Timuran.

Tokoh masyarakat yang diambil sebagai sumber data penelitian ini adalah para pelaku seni wayang. Ki Suwoto, Ki Wardaya, adalah Ki Sihab adalah dalang yang masih aktif. Sedangkan Pak Sukar merupakan panjak senior yang masih aktif.

\section{Data Penelitian}

Data dalam penelitian terdiri dari 4 hal, yang dijelaskan seperti berikut ini.

a. Pertunjukan wayang kulit dalang wayang kulit Jawa Timuran. Dari sisi pertunjukan akan diperoleh data tentang suluk, antawecana, bahasa, sabetan, instrumen pengiring, dan susunan adegan.

b. Cerita (kumpulan lakon) yang dimiliki dalang wayang kulit Jawa Timuran.

c. Informasi dari dalang berkaitan dengan proses kreatif, pembelajaran menjadi dalang, ide-ide berkaitan dengan pengembangan wayang Jawa Timuran.

d. Informasi dari para tokoh masyarakat dalam bidang wayang berkaitan sejarah perkembangan wayang Jawa Timuran.

\section{Lokasi Penelitian}

Lokasi penelitian yang akan dilaksanakan ini adalah Jawa Timur, tepatnya 3 wilayah berkembangnya cengkok wayang kulit Jawa Timuran, yaitu Mojokerto, Lamongan, dan Jombang. Tiga lokasi lainnya, yakni Surabaya, Porong, dan 
Malang telah diteliti. Hasil penelitian dari penelitian tersebut akan dijadikan acuan dalam penarikan simpulan akhir. Wayang kulit Jawa Timuran di tiga lokasi tersebut akan diteliti dalam kurun waktu 2 tahun. Panjangnya waktu tersebut dimaksudkan agar mencapai hasil yang maksimal dibandingkan hasil penelitian terdahulu. Namun karena penelitian Fundamental hanya sampai 2 tahun, maka penelitian tahun pertama akan dilaksanakan di Mojokerto. Penentuan lokasi tersebut berdasarkan pertimbangan bahwa wilayah tersebut dekat dengan Surabaya. Kedekatan akan memungkinkannya adanya aliran penyebaran pengaruh. Penelitian kedua dilakukan di Jombang. Pemilihan wilayah tersebut berdasarkan pertimbangan bahwa Jombang merupakan wilayah yang dekat dengan Mojokerto. Lamongan akan diteliti pda tahap berikutnya, mengingat Lamongan yang merupakan wilayah pesisir tentunya memiliki keunikan.

\section{Pengumpulan Data}

Metode pengumpulan data yang dipakai adalah metode wawancara, pengamatan dan dokumentasi. Menurut Danandjaja, untuk dapat melaksanakan wawancara dan pengamatan yang baik dan bebas kita harus menciptakan suatu keadaan yang bebas dan dekat antara peneliti dan informan (1990:99; Sudikan, 2001:86). Sedangkan dokumen menurut Sunarto (2001:155) meliputi bahan dokumen dan catatan tertulis. Dokumen dapat berupa biografi, otobiografi, catatan harian, surat, termasuk di dalamnya gambar-gambar dan karya seni. Jadi seperti yang telah dikemukakan oleh Spradly (1997:11), selain pengamatan dan wawancara, pengumpulan data juga dilakukan dengan dokumentasi, yaitu dengan memperhatikan berbagai artefak budaya.

1. Metode pengamatan digunakan untuk mengamati pementasan dalang wayang kulit Jawa Timuran. Dari pengamatan tersebut akan diperoleh data tentang sendhon, bahasa, sabetan, instrumen pengiring, dan susunan adegan.

2. Metode wawancara dilakukan kepada dalang wayang Jawa Timuran dan tokoh masyarakat. Wawancara dengan dalang dilakukan untuk mengidentifikasi cerita-cerita yang dimiliki, dalang wayang kulit Jawa Timuran. Di samping itu wawancara dengan dalang dimaksudkan untuk memperoleh data tentang suluk, antawecana, bahasa, sabetan, instrumen pengiring, dan susunan adegan yang dimiliki dalang. Sedangkan wawancara dengan tokoh masyarakat dilakukan untuk memperoleh data tentang sejarah wayang Jawa Timuran.

3. Metode dokumentasi digunakan untuk menggali berbagai artefak budaya yang berkaitan dengan bentuk-bentuk wayang, buku-buku, foto-foto yang dimiliki dalang sebagai warisan atau sumber belajar dalang.

\section{Analisis Data}

Menurut Hasan (1990: 16), hasil analisis data dalam penelitian kualitatif berbentuk deskripsi fenomena. Analisis data dilakukan secara simultan, bersamaan dengan pengumpulan data atau setelah sejumlah data terkumpul (Hasan, 1990:16; Huda, 1990:91; Miles, 1992:73).

Metode yang digunakan dalam analisis data dalam penelitian ini adalah metode analisis deskriptif yang dipandu oleh teori stilistika. Sesuai dengan pendapat Idrus (2007:120) bahwa metode deskriptif digunakan untuk membuat penggambaran tentang sesuatu keadaan secara obyektif dalam suatu deskripsi situasi. Sedangkan model analisis yang digunakan seperti yang disarankan oleh 
Miles dan Huberman (2007) yaitu model analisis interaktif. Model interaktif terdiri dari tiga bagian, yaitu reduksi data, penyajian data, dan penarikan kesimpulan

Data-data yang terkumpul dari hasil wawancara, pengamatan, dan pengecekan dokumen berkaitan dengan dalang dan pementasan wayang kulit Jawa Timuran, belum merupakan data matang yang siap disajikan, melainkan perlu direduksi. Perlu ditandai mana yang dikembangkan dan mana yang dibuang karena tidak diperlukan. Kemudian disusun dan disajikan dengan diperkaya dan diperdalam dengan berbagai kutipan yang diperlukan. Proses penarikan kesimpulan berlangsung sejak saat pengumpulan dan reduksi data. Namun simpulan tersebut belum final. Simpulan akan disempurnakan dengan proses verifikasi, yaitu dengan mengingat hasil-hasil temuan terdahulu dan melakukan cek silang dengan temuan lainnya.

Kesimpulan sempurna akan diperoleh pada tahap atau tahun ke II. Dari simpulan penelitian tahun I digabung dengan hasil penelitian terdahulu, yakni kekhasan cengkok Trowulan dikaitkan dengan cengkok Lamongan. Akan dapat dilihat dengan jelas perjalanan masuknnya pengaruh dalam tubuh wayang kulit Jawa Timuran.

\section{HASIL DAN PEMBAHASAN}

Hasil penelitian akan diuraikan berdasarkan tiga masalah yang telah dirumuskan, yakni asal mula cengkok wayang kulit Trowulan, peta penyebaran wayang kulit cengkok Trowulan, karakteristik pertunjukkan wayang kulit cengkok Trowulan. Ketiga hal tersebut akan diuraikan secara rinci dan runtut seperti di bawah ini.

\section{Asal Mula Wayang Kulit Cengkok Trowulan}

Pembahasan asal mula wayang kulit cengkok Trowulan akan dimulai dari asal usul dalang cikal bakal cengkok Trowulan, yakni Ki Pit Asmoro. Perkembangan kesenian wayang di Trowulan sebagai bagian dari wilayah Mojokerto ternyata tidak hanya memiliki satu cengkok. Ada cengkok lain yang berkembang di wilayah tersebut. Pembahasan mengenai asal-asul tersebut akan diuraikan secara rinci seperti di bawah ini.

\section{Sejarah Terbentuknya Cengkok Trowulan}

Wayang kulit Jawa Timuran menurut Ki Yohan Susilo (wawancara 15 Maret 2015), seorang dalang dari Sidoarjo, berasal dari seorang empu bernama Ki dalang Gunarso yang berdomisili di daerah Waru Sidoarjo. Ki Gunarso memiliki banyak murid, namun yang selanjutnya memiliki pengaruh kuat dalam pengembangan wayang kulit Jawa Timuran di wilayah Gerbangkertasusila ada tiga orang, yakni Ki Sutomo, Ki Sulaiman, dan Ki Pit Asmoro.

Ketiga murid tersebut setelah tamat belajar atau nyantrik dengan metode tradisional mereka mengembangkan bakat ndalangnya ke wilayah yang berbeda. Ki Sutomo mengembangkan wayang Jawa Timuran ke arah utara, yakni wilayah Sidoarjo bagian utara dan Surabaya. Gaya ndalang Ki Sutomo terkenal dengan sebutan cengkok Surabaya. Ki Sutomo memiliki banyak murid yang tersebar sampai Sidoarjo bagian barat yakni Krian dengan Ki dalang Sutrisno. Sayangnya 
dalang cengkok Surabaya sudah mulai langka. Ki Sutrisno sebagai dalang senior juga sudah tidak aktif pentas dan tidak memiliki murid.

Ki Sulaiman mengembangkan wayang Jawa Timuran ke arah Selatan, yakni Porong. Pengaruh Ki Sulaiman mencapai Malang. Kaset dan CD Ki Sulaiman meskipun beliau sudah almarhum ternyata tersebar sampai wilayah Malang. Ki Sulaiman terkenal dengan cengkok Porong, karena beliau tinggal di Porong. Ki Sulaiman juga memiliki murid yang banyak, bahkan lebih banyak dibanding kedua sahabatnya. Hal tersbeut dibuktikan dengan semaraknya cengkok Porong, yang berkembang sampai Surabaya, Sidoarjo, Porong, Malang, bahkan Mojokerto dan Jombang. Murid-murid Ki Sulaiman masih aktif dan sebagian besar masih muda, seperti Ki Yohan Susilo.

Ki Pit Asmoro mengembangkan seni pewayangan ke wilayah Trowulan, tempat asal-usulnya. Beberapa dalang senior seperti Ki Pitoyo, Ki Suwoto, Ki Sihab, Ki Wardoyo dan panjak Sukar (wawancara 15-20 April 2015) menyebut Ki Pit Asmoro sebagai cikal bakal cengkok Trowulan. Ki Suwoto (wawancara 15 April 2015) menegaskan bahwa Ki Pit Asmoro sebagai kakeknya. Ayah beliau yakni Ki Safi'i memang murid dari Ki Pit Asmoro. Hubungan mereka yang sangat dekat dalam kesenian wayang sehingga mendekatkan pula hubungan keluarga, meskipun sebenarnya mereka tidak punya hubungan darah.

Ki Pit Asmoro juga merupakan tokoh legendaris dalam kasanah wayang kulit Jawa Timuran di Trowulan seperti halnya Ki Sulaiman di Porong. Kebesaran namanya menjadikan tempat tinggalnya Trowulan diangkat sebagai nama cengkok wayang yang ditekuninya. Ki Pit Asmoro sudah lama meninggal dunia namun namanya tetap diabadikan oleh masyarakat dan para pengembang wayang Trowulanan sebagai tokoh utama pendiri cengkok Trowulan.

$\mathrm{Ki}$ Pit Asmoro memiliki darah atau keturunan dalang. Ayahnya bernama Ki Condro juga seorang dalang. Bakat dalang Ki Pit Asmoro tidak diteruskan oleh putra-putrinya. Namun Ki Pit Asmoro memiliki banyak murid sehingga cengkok Trowulan mendominasi pementasan wayang kulit di Mojokerto.

\section{Ki Pitoyo Dalang Senior Cengkok Trowulan}

Ki Pitoyo tinggal di desa Sasap, Suko, Mojokerto. Ki Pitoyo merupakan dalang yang memiliki bakat keturunan. Ayah Ki Pitoyo yang bernama Ki Safi'i juga merupakan seorang dalang. Ki Safi'ilah yang merupakan murid atau cantrik langsung dari Ki it Asmoro. Ki Safi'i belajar ndalang dengan pola nyantrik kepada Ki Pit Asmoro (Pitoyo, wawancara 15 April 2015). Murid belajar ndalang dengan tinggal bersama sang guru. Cantrik belajar pada malam hari, terutama mengikuti pertunjukkan ke tempat sang guru pentas. Cantrik tidak hanya belajar. Mereka juga turut membantu pekerjaan rumah dan bahkan mengerjakan sawah ladang yang dimiliki sang guru. Setelah dirasa memiliki bekal yang cukup sang guru baru memberikan kepercayaan untuk pentas menggantikan atau mewakili sang guru apabila tanggapan atau permintaan sedang bersamaan.

Ki Pitoyo merupakan putra dari Ki Safi'i, seorang dalang Trowulan juga. Ki Safi'i semasa hidupnya memiliki banyak murid atau cantrik. Menurut Ki Suwoto (wawancara 16 Maret 2015) yahandanya tersebut memiliki dua belas orang murid. Dari dua belas murid tersebut ada empat orang dalang yang menjadi dalang 
sukses, yakni Ki Seno Aji di Jonggrong, Mojoagung, Ki Arjun di Njagan Trowulan, Ki Marjun di Njawina, Mojoagung, Teguh Sutrisno di Mulangagung. Ki Safi'i merupakan murid langsung dari Ki Pit Asmoro.

Ki Pitoyo memiliki empat orang saudara, empat orang laki-laki, dan seorang perempuan. Keempat saudara tersebut adalah Hadi Utama, Pitoyo, Heriyanto, Suwoto, dan Endang Srimuji. Keempat putra tersebut semuanya mewarisi bakat dalang dari Ki Safi'i. Namun tidak semuanya berdiri sebagai dalang. Putra yang menjalankan amanah sebagai dalang ada dua yaitu Ki Pitoyo dan Ki Suwoto.

Kedua saudara tersebut memiliki cara belajar yang berbeda. Ki Suwoto menjalani pendadaran sebagai murid seperti murid-murid Ki Safi'i lainnya. Ki Suwoto (wawancara 16 April 2015) belajar bersama murid yang lain. Beliau juga mengikuti pertunjukkan ayahandanya setiap malam. Oleh karena itu beliaulah yang mewarisi semua dokumen ayahandanya seperti buku pakem lakon wayang berupa catatan tangan dari Ki Safi'i.

Ki Pitoyo menempuh cara yang berbeda. Ki Pitoyo (wawancara 15 April 2015) tidak menjadi cantrik atau murid Ki Safi'i. Ki Pitoyo mengakui bahwa beliau tidak suka wayang dan tidak pernah pegang wayang meskipun ayahandanya dalang. Beliau belajar ndalang secara autodidak. Secara tidak sengaja Ki Pitoyo sering melihat dan mendengar ayahandanya memberi pelajaran ndalang kepada murid-muridnya.

Ki Pitoyo memiliki niat dan kemauan ndalang pada tahun 1989, ketika sudah berusia 44 tahun. Ki Pitoyo pentas wayang pertama kali dimotivasi oleh teman-temannya. Pentas dilaksanakan di pasar Brangkal. Ki Pitoyo dengan niat yang bulat dan mengucap bismillah, bisa pentas semalam suntuk dengan cerita Dewa Ruci. Ki Pitoyo merasa memiliki banyak kekurangan dalam olah vokal dalang pada waktu itu.

Ki Pitoyo melanjutkan belajar melalui majalah Panyebar Semangat, sebuah media berbahasa Jawa yang terbit satu minggu sekali. Majalah tersebut merupakan majalah populer yang berisi rubrik sastra juga, seperti carita cekak, carita sambung, gegutitan, carita rakyat, carita misteri, dan pedalangan. Rubrik pedalangan merupakan sumber belajar $\mathrm{Ki}$ Pitoyo untuk memperkaya perbendaharaan cerita. Rubrik tersebut masih ada sampai sekarang.

Ki Pitoyo sejak pentas pertamanya terus mendapatkan sambutan dari masyarakat Trowulan. Pementasannya tidak pernah kosong, terutama di bulanbulan baik yang digunakan masyarakat untuk menyelenggarakan hajatan. Beliau menerima tanggapan dari Trowulan, Mojokerto dan luar Trowulan, seperti Jombang, Lamongan, Sidoarjo, bahkan sampai Surabaya, Pasuruan, dan Malang.

Ki Pitoyo sampai saat ini masih memperoleh tanggapan penuh dalam sebulan pada bulan baik. Tanggapan penuh tersebut tidak berarti 30 hari, namun 8-10 kali pentas pada Sabtu dan Minggu. Telah terjadi pergeseran budaya untuk menentukan hari baik dalam menyelenggarakan hajatan. Masyarakat Jawa sebagian besar saat ini sudah tidak terlalu menuruti petungan Jawa. Hari baik menurut sebagian besar masyarakat sekarang adalah hari Sabtu dan Minggu.

Tarip bukan hal yang dipatok oleh Ki Pitoyo. Namun masyarakat sudah bisa memberikan harga kepada pertunjukkan seorang dalang. Ki Pitoyo secara terbuka menyebutkan bahwa imbalan yang beliau terima sekitar lima belas juta setiap 
pentas. Hal tersebut sudah termasuk tambahan campursari yang memang dimilikinya.

Pementasan wayang Ki Pitoyo memiliki cirikhas. Dalang tersebut banyak melakukan kreasi. Ki Pitoyo membaca perkembangan seni di sekitarnya. Ketika kesenian wayang sudah mulai mengalami kemunduran, dan kesenian campur sari mendapatkan tempat baru di hati masyarakat, maka beliau memadukan kesenian wayang dengan campursari. Ki Pitoyo menambahkan peralatan musik campursari ke dalam pentas wayangnya.

Ki Pitoyo memulai pertunjukkan pada pukul 21.00. Pertunjukkan dimulai dengan pentas tari Remo dilanjutkan campursari sampai pukul 24.00. Wayang dimulai paling awal pukul 24.00. Campursari akan disajikan lagi pada saat adegan gara-gara.

Wayang Jawa Timuran cengkok Trowulan memiliki kekhasan dalam bentuk tokoh wayang. Salah satu kekhasan tersebut terletak pada tokoh Kresna. Tokoh Kresna Trowulan berbeda dengan Porongan apalagi Jawa Tengah. Perbedaan tersebut terletak pada posisi kepala. Kresna Trowulan ujung atas kuluknya (topinya) agak ke belakang. Sedangkan Kresna Porongan ujung kuluknya ke depan, tegak dari bawah.

Ki Pitoyo memiliki empat orang murid sebagai calon penerusnya. Istilah murid pada saat ini sudah tidak tepat disebut nyantrik, karena pola pembelajarannya sudah jauh berbeda dengan istilah nyantrik. Murid sekarang, khususnya murid Ki Pitoyo sudah tidak ikut tinggal di rumah Ki Pitoyo. Para murid cukup datang pada saat tertentu dan pulang kembali ke rumahnya, tanpa dibebani pekerjaan rumah sang Guru. Keempat murid tersebut adalah: Bagus, Malkan, Susana, dan Welly. Bagus belajar ndalang sejak duduk di bangku SMA. Bakat seninya mengarahkan Bagus melanjutkan kuliah di ISI Solo. Setelah kuliah di ISI Bagus melanjutkan belajar wayang gaya Jawa Tengah. Malkan merupakan murid tertua, yakni berusia 55 tahun. Ki Malkan ini sudah mulai berani pentas sendiri. Susana merupakan murid perempuan dan masih muda. Usianya masih 33 tahun. Susana juga menjadi sindhen Ki Pitoyo. Welly merupakan murid paling muda usianya. Murid tersebut masih kuliah di jurusan Bahasa Daerah Unesa. Welly sudah berani pentas dalam pakeliran padat. Menurut Ki Pitoyo, Welly masih akan konsentrasi pada kuliah. Ia akan melanjutkan belajar ndalang setelah kuliahnya selesai.

\section{Peta Penyebaran Wayang Kulit Jawa Timuran Cengkok Trowulan}

Wayang kulit yang berkembang di Mojokerto memiliki dua versi, yakni versi Jawa Tengah dan Jawa Timuran. Kedua versi tersebut menurut Ki Suwoto (wawancara 16 April 2015) memiliki perbedaan yang mendasar yakni pada musik pengiringnya. Versi Jawa Tengah menggunakan pengiring gamelan laras pelog, sedangkan laras slendro hanya sebagai pelengkap. Sebaliknya, wayang Jawa Timuran menggunakan iringan karawitan laras slendro, sedangkan laras pelog sebagai pelengkap.

Kedua versi tersebut masih berkembang semua di Mojokerto. Menurut pendapat dan pengalaman seorang panjak wayang kulit bernama Sukar (wawancara 15 April 2015), dari kedua versi tersebut versi Jawa Timuran yang 
lebih diminati oleh masyarakat Mojokerto. Hal tersebut berkaitan dengan bahasa yang digunakan. Bahasa Jawa Timuran yang digunakan oleh dalang Jawa Timuran lebih berterima di telinga masyarakat Mojokerto.

Sebelum membahas peta penyebaran cengkok Trowulan, akan dibicarakan lebih dahulu berkembangnya cengkok wayang Kulit Jawa Timuran di Mojokerto. Pada bagian sebelumnya telah disebut bahwa di Mojokerto berkembang dua versi wayang kulit, yakni Jawa Timuran dan Jawa Tengah. Wayang kulit Jawa Timuran di Mojokerto didominasi oleh cengkok Trowulan, dengan empunya Ki Pit Asmoro. Murid-murid Ki Pit Asmoro mengembangkan cengkok Trowulan keluar dari Trowulan bahkan keluar dari Mojokerto, seperti ke Jombang. Ada cengkok lain yang pernah berkembang di Mojokerto yang disebut sebagai cengkok Ngastemi. Namun cengkok tersebut tidak sekuat Trowulan. Hal tersebut diakui sendiri oleh Ki Sihab (wawancara 17 April 2015).

Ngastemi adalah nama sebuah desa. Desa tersebut pernah dipimpin oleh Lurah Wardoyo (Almarhum). Ki Lurah Wardoyo itulah yang menjadi cikal bakal cengkok Ngastemi. Nama cengkok wayang kulitnya dikenal dengan nama Ngastemi. Seperti halnya Ki Pit Asmoro yang tinggal di Trowulan, Trowulan dijadikan nama cengkok.

Ki Wardoyo belajar ndalang ke Kediri. Guru beliau bernama Ki Patrem. Pada umumnya wayang di wilayah Kediri mengikuti gaya Jawa Tengah, sesuai dengan bahasa yang digunakan oleh masyarakat Kediri yang dekat dengan bahasa baku, yakni bahasa Jawa Tengah. Namum, wayang Ki Patrem menggunakan gaya Jawa Timuran. Ki Patrem memiliki banyak siswa, di antaranya yang masih diingat oleh Ki Sihab adalah Ki Jaet dan Ki Parman.

$\mathrm{Ki}$ Wardoyo mewariskan bakat ndalangnya kepada putranya bernama $\mathrm{Ki}$ Suwardono. Namun setelah Ki Suwardono meninggal, tidak ada putra putrinya yang mewarisi bakat seninya. Bakat mendalang tersebut diturunkan kepada $\mathrm{Ki}$ Sihab yang merupakan cucu keponakan. Ki Sihab memiliki nama lengkap Ki Sihab Dermawisastra.

Ki Sihab adalah satu-satunya dalang yang masih hidup dari cengkok Ngastemi. Usianya yang sudah lanjut, yakni sekitar 71 tahun dan penyakit asma yang dideritanya menyebabkan lelaki tersebut tidak bisa pentas wayang lagi. $\mathrm{Ki}$ Sihab juga tidak memiliki murid sama sekali. Hal tersebut disebabkan tidak adanya putra putri Ki Sihab yang mau meneruskan bakat ndalang ayahandanya. Orang lain juga tidak ada yang berminat meneruskan cengkok Ki Sihab. Menurut Ki Sihab cengkok Ngastemi tersebut memang agak sulit dibandingkan cengkok Trowulan.

Ada perbedaan antara cengkok Ngastemi dan Trowulan. Menurut Ki Sihab salah satu perbedaan yang tampak dengan jelas terletak pada untaian kata-kata bagian pelungan. Untaian kata-kata tersebut dilagukan dalang pada awal pertunjukkan. Kita perhatikan bagian pelungan Ki Sihab sebagai berikut:

Ana purwakaning janma

Kendel larapane

Sinelehake bumi suci

Sedangkan berikut ini pelungan Trowulan: 
Rep sirep sirep saking kersaningsun

Sekar gawe ginawe kinaryo ramining kidung

Binarung swaraning gendhing Ganda kusuma

Perbedaan lain menurut Ki Sihab terletak pada pemberian makna. Wayang Ngastemi lebih mengutamakan aspek filosofis dari pada hanya sebuah cerita. Contohnya, dalang juga menjelaskan makna gelung yang dipakai para pandhawa. Gelung tersebut diberi nama gelung supit urang, bagian atas gelung tidak tertutup, melainkan renggang atau longgar, tidak bertemu. Gelung tersebut tidak dimiliki oleh tokoh para kurawa. Hal tersebut menggambarkan bahwa pemakainya memiliki, kelonggaran atau kesabaran, memiliki sifat baik.

Sangat disayangkan bahwa Ki Sihab, satu-satunya dalang yang mewakili dalang cengkok Ngastemian tersebut tidak memiliki penerus atau pewaris dan juga tidak memiliki dokumentasi. Di kala diminta performent tanpa pentaspun beliau juga kesulitan. Secara fakta cengkok Ngastemi sudah punah dengan berhentinya Ki Sihab dari kegiatan mendalang.

Sudah disinggung bahwa wayang Jawa Timuran cengkok Trowulan berkembang di sebagian besar wilayah Mojokerto. Meskipun terdapat cengkok lain, seperti cengkok Porong, namun cengkok Trowulan merupakan cengkok wayang Jawa Timuran yang sangat diminati oleh masyarakat Mojokerto. Cengkok Trowulan tersebar di wilayah Mojokerto bagian barat, timur, selatan maupun utara wilayah Mojokerto.

Cengkok Trowulan berkembang sampai Jombang. Hal tersebut telah berlangsung semasa Ki Pit Asmoro. Semasa dengan Ki Pit Asmoro, di Jombang eksis seorang dalang bernama Ki Winoto yang bertempat tinggal di Ngoro, Pathuk, Jombang.

Cengkok Trowulan di wilayah Jombang juga digemari. Hal tersebut dibuktikan dengan eksisnya dalang Rohman saat ini. Ki Rohman juga bertempat tinggal di Ngoro. Ki Rohman menjadi dalang sama prosesnya dengan Ki Pitoyo. Ki Rohman juga tidak melalui proses nyantrik maupun belajar langsung kepada seorang guru (Sukar, wawancara 17 April 2015).

Menurut penuturan Pak Sukar (wawancara 17 April 2015), pimpinan panjak dalang Rohman, di Jombang dalang Rohman merupakan dalang tiban. Ki Rohman bisa ndalang tanpa belajar. Namun sebenarnya Ki Rohman berusaha belajar sendiri. Ki Rohman menyimak kaset dari pementasan dalang Winoto. Kegiatan menyimak yang sungguh-sungguh tersebut dapat memberikan hasil yang sangat memuaskan sehingga dapat mengangkat nama dalang Rohman sebagai dalang terkenal di wilayah Jombang.

Sebutan dalang tiban dikuatkan dengan tidak adanya keturunan dalang dalam darah Ki Rohman. Ayahanda dalang Rohman bukan seorang dalang. Ki Rohman juga bukan seorang pemangku atau pelaku seni. Beliau bekerja sebagai pegawai pemerintah. Istri beliau juga bekerja sebagai pegawai pemerintah. Di sisi lain, pekerjaan dan jabatan sebagai sekretaris camat atau sekcam justru dapat melambungkan nama Ki Rohman. Pergaulannya semakin luas dan dihormati oleh masyarakat. 


\section{PENUTUP}

Wayang kulit Jawa Timuran memiliki kekhasan sebagai wayang Jawa Timuran pada aspek peralatan dan estetika. Aspek peralatan menunjukkan bahwa wayang Jawa Timuran diiringi oleh gamelan laras slendro dengan kendang berukuran panjang sehingga menghasilkan suara dong..dong...dong. Suara tersebut yang dijadikan onomatope sehingga wayang Jawa Timuran disebut wayang cek dong.

Wayang Jawa Timuran memiliki beraneka cengkok. Wayang yang hidup di Mojokerto didominasi oleh cengkok Trowulan. Disebut cengkok Trowulan karena cikal bakal cengkok tersebut bernama Ki Pit Asmoro, berdomisili di Trowulan.

Wayang cengkok Trowulan berasal dari induk yang sama dengan cengkok yang lain. Aneka cengkok tersebut berasal dari induk yang sama yakni Ki Guru Dalang Gunarso. Murid Ki Gunarso mengembangkan kesenian wayang ke berbagai penjuru di Jawa Timur dan eksis dengan kekhasan masing-masing.

Ki Pit Asmoro memiliki banyak murid secara langsung maupun tidak langsung. Murid belajar secara langsung dengan menerima pelajaran dari gurunya dan mengikuti pagelarannya. Murid juga bisa belajar secara tidak langsung dengan mendengarkan kaset dari guru yang diidolakan. Meskipun demikian, sang Guru tetap mengakuinya sebagai murid. Hal tersebut dialami oleh Ki Pitoyo murid Ki Safi'I dan Ki Rohman murid dari Ki Winoto.

Ki Pitoyo merupakan dalang senior dalam cengkok Trowulan. Beliau melakukan kreasi dengan menggabungkan wayang dengan campursari. Ki Pitoyo berusaha mempertahankan eksistensi wayang di tengah berkembangpesatnya campursari.

\section{Daftar Pustaka}

Danandjaja, James. 1984. Folklor Indonesia (Ilmu Gosip, Dongeng dan lainlain). Jakarta: Grafiti Pers.

Djumiran, dkk. 1996. Wayang Kulit Jawa Timuran. Surabaya: Dinas Pendidikan dan Kebudayaan Provinsi Jawa Timur.

Hasan, Zaini M. 1989. "Karakteristik Penelitian Kualitatif" dalam Pengembangan Penelitian Kualitatif dalam Bidang Bahasa dan Sastra. Malang: Y3A.

Hardjana, Andre. 1994. Kritik Sastra Sebuah Pengantar. Jakarta: Gramedia.

Huda, Nuril. 1990. "Pengembangan Penelitian Kualitatif dalam Studi Perkembangan Bahasa Anak" dalam Pengembangan Penelitian Kualitatif dalam Bidang Bahasa dan Sastra. Malang; Y3A.

Hutomo, Suripan Sadi. 1987. "Cerita Kentrung: Teori Von Sedow" dalam Media Pendidikan dan Ilmu Pengetahuan XI (31), Nopember: 11-19. Surabaya: IKIP Surabaya.

------- 1991 Mutiara yang Terlupakan. Malang: Yayasan 3A.

Idrus, Muhammad. 2007. Metode Penelitian Ilmu-Ilmu Sosial (Pendekatan Kualitatif dan Kuantitatif). Yogyakarta: UII Press Yogyakarta.

Koentjaraningrat. 1984. Kebudayaan Jawa. Jakarta: Balai Pustaka.

Miles, Matthew B. dan A. Michael Huberman. 2007. Analisis Data Kualitatif (diindonesiakan oleh Tjetjep Rohendi Rosidi). Jakarta: Universitas Indonesia Press. 
Miles, Matthew B. dan a Michael Huberman

1990 Analisis Data Kualitatif (diindonesiakan oleh Tjetjep R.R.). Jakarta: UI Press.

Moleong, Lexy J. 2000. Metode Penelitian Kualitatif. Bandung: Remaja Rosdakarya.

Nugroho, Amin. 2001. "Sejarah Wayang Purwa Satleraman 1-3 dalam Panyebar Semangat (No.7-9, Februari-Maret 2001). Surabaya: PT Pancaran Semangat Jaya.

Pairin, Udjang. 2013. Pemetaan Cengkok Wayang Jawa Timuran sebagai Upaya Melestarikan Seni Tradisional. Laporan Penelitian (Tidak Diterbitkan). Surabaya: LPPM Unesa.

Parwoto. 1985. "Nilai-nilai Pendidikan dalam Rama Tambak oleh Ki Dalang Sulaiman" . Skripsi. Surabaya: Jurusan Pendidikan Bahasa Daerah, FBS, IKIP Negeri Surabaya

Rahayu, Eko Wahyuni dan Darni. 2007. Dalang Wayang Kulit Wanita Jawa Timur (Versi Jawa Tengah). Laporan Penelitian. Surabaya: Lembaga Penelitian Unesa.

Rass, J.J. 1985. Bunga Rampai Sastra Jawa Mutakhir. Jakarta: Grafiti Pers.

Santosa, Yusuf Budi. 1985. "Bahasa dan Struktur Pagelaran Wayang Kulit Purwa Jawa Timur Lakon Indrajit Gugur serta hubungannya dengan Kurikulum Bahasa Jawa si SMA.” Skripsi. Surabaya: Jurusan Pendidikan Bahasa Daerah, FBS, IKIP Negeri Surabaya.

Spradley, James P. 1997. Metode Etnografi (Diindonesiakan oleh Misbah Z.E.). Yogyakarta: Tiara Wacana.

Sudikan, Setya Yuwana. 2001. Metode Penelitian Kebudayaan. Surabaya: Citra Wacana.

Supratno, Haris. 2010. Sosiologi Seni: Wayang Sasak Lakon Dewi Rengganis dalam Kontes Perubahan Masyarakat di Lombok. Surabaya: Unesa University Press.

Susilo, Yohan. 2001. "Tindak Tutur Lokusi Pedalangan Gaya Jawa Timuran dalam Anoman Duta Dalang Ki Sulaiman”. Skripsi. Surabaya: Jurusan Pendidikan Bahasa Daerah, FBS, IKIP Negeri Surabaya. 